\title{
Economic Analysis Comparison between Solar Photovoltaic and Diesel Generator for Water Pumping System in an Indonesia Rural Karsts Area
}

\author{
Ahmad Agus Setiawan ${ }^{\mathrm{a}}$, Satria Antariksa Ramadhan ${ }^{\mathrm{a}}$, Nur Setyo Wahyuni ${ }^{\mathrm{a}}$, \\ Atika Nurul Hidayah ${ }^{\mathrm{a}}$, Muhammad Luqman Nur Rouf Arifin ${ }^{\mathrm{a}}$, Hempri Suyatna ${ }^{\mathrm{b}}$ \\ ${ }^{a}$ Department of Engineering Physics, Faculty of Engineering, Universitas Gadjah Mada. Jl. Grafika No. 2, Yogyakarta 55281, Indonesia \\ ${ }^{b}$ Department of Social Development Studies, Faculty of Social and Politic Science, Universitas Gadjah Mada. Jl.Sosio Yustisia, Bulaksumur, \\ Yogyakarta 55281, Indonesia
}

\begin{abstract}
Photovoltaic and diesel generator are two types of small generator often used in remote areas in Indonesia. One of remote area in Indonesia that has ever used both systems in water pumping system is Purwodadi Village, Tepus district located at karsts area of Gunungkidul. The economical comparison between both technologies will be analyzed using lifecycle cost calculation and HOMER simulation. The analysis shows that using photovoltaic for water pumping system only spend 3/4 times of diesel generator cost. On the other hand, HOMER analysis shows that the cost of energy value for photovoltaic usage is $0.312 \$ / \mathrm{kWh}$, and cost of energy value for diesel generator is $0.390 \$ / \mathrm{kWh}$.
\end{abstract}

Keywords: diesel generator; homer; photovoltaic; water pumping

\begin{tabular}{|c|c|}
\hline Nomencl & \\
\hline A & annual cost $(\$)$ \\
\hline $\mathbf{A}_{\mathrm{O \& M}, \mathrm{S}}$ & the total cost for maintenance for diesel $(\$)$ \\
\hline $\mathbf{C}_{\text {diesel }}$ & total diesel system capital cost $(\$)$ \\
\hline $\mathbf{C}_{\mathrm{E}}$ & the cost incurred for each specific purpose of maintenance (\$) \\
\hline $\mathbf{C}_{M}$ & the cost of maintenance for each specific purpose $(\$)$ \\
\hline $\mathbf{C}_{\mathbf{M} \text {,air }}$ & annual cost of diesel engine air filter changes $(\$)$ \\
\hline $\mathrm{C}_{\mathrm{M}, \mathrm{cool}}$ & annual cost of diesel engine coolant $(\$)$ \\
\hline $\mathbf{C}_{\text {Diesel fuel }}$ & net present value of lifetime diesel fuel costs $(\$)$ \\
\hline $\mathbf{C}_{\text {M.oil }}$ & annual cost of diesel engine oil changes $(\$)$ \\
\hline $\mathbf{C}_{\mathbf{M}, o i l \text { filt }}$ & annual cost of diesel engine oil filter changes $(\$)$ \\
\hline $\mathrm{C}_{\text {O\&M,PV }}$ & total lifecycle operating and maintenance cost for photovoltaic (PV) system (\$) \\
\hline CPV & capital cost for solar array $(\$)$ \\
\hline $\mathbf{F}$ & load factor \\
\hline
\end{tabular}

\footnotetext{
* Corresponding author. Tel.: +62 81327006577

E-mail address: : a.setiawan@ugm.ac.id
} 


\begin{tabular}{|ll|}
\hline $\mathbf{F}_{\mathbf{E}}$ & the components replacement frequency \\
$\mathbf{F}_{\mathbf{M}}$ & the frequency of maintenance in a year \\
$\mathbf{F V}$ & future value $(\$)$ \\
$\mathbf{G d}$ & the time of diesel operation for a year $(\mathrm{h})$ \\
$\mathbf{H d}$ & the total amount of time during the operational hours of diesel in a year $(\mathrm{h})$ \\
$\mathbf{H p}$ & the number of days in a year -yr \\
$\mathbf{i}$ & annual discount rate $(\% / \mathrm{yr})$ \\
$\mathbf{P c l e a n i n g}$ & net present value of solar panel cleaning cost $(\$)$ \\
$\mathbf{P i n v}$ & net present value of inverter replacement cost $(\$)$ \\
$\mathbf{P g e n}$ rate & power rating for diesel generator $(\mathrm{kW})$ \\
$\mathbf{P p}$ & pump power $(\mathrm{W})$ \\
$\mathbf{P V}$ & present Value $(\$)$ \\
$\mathbf{U i n v}$ & unit cost of the electronics $(\$ / \mathrm{W})$ \\
$\mathbf{U}_{\mathbf{N P V}, \text { diesel }}$ & price of subsidized diesel fuel $(\$)$ \\
$\mathbf{U} \mathbf{P V}$ & unit cost $(\$ / \mathrm{W})$ \\
$\mathbf{V}$ & the number of litres of fuel needed in one day $(\mathrm{L})$ \\
$\mathbf{W p}$ & rated power of the solar array calculated $(\mathrm{W})$ \\
\hline
\end{tabular}

\section{Introduction}

Currently, the need for clean water is fundamental to life. However, getting clean water is not an easy thing in some areas. Sureng village is a village located in Gunung Kidul, Yogyakarta, which is still experiencing drought. Drought in this region is due to the structure made of karst soil, making it difficult for the supply of water taken from groundwater. Some of the ways in which local communities to get water is by the rainwater harvesting, or taking water from a nearby river, Kali Sureng, which is about two km away from the settlement.

In 2007, the Department of Public Works conducted water pumping program that works to pump water from the Kali Sureng to a shelter within $100 \mathrm{~m}$ of a residential community [1]. This was done by pumping water using a pump that was powered by diesel. In that year, with the addition of a pump, water was pumped up to the farthest point in Sureng Village. However, diesel-powered water pumping has significant operational cost. In addition, diesel generator used to generate electricity also does not have a long life. This causes the water pumping system to stop operating and community re-experiencing water shortages.

In 2010 and 2011, a team from the Department of Engineering Physics, Universitas Gadjah Mada and supported by the Ministry of Education and Culture conducted a study to replace the diesel pump with a pump that was powered by solar panels [1]. The design called Solar Water Pumping System is then realized in 2012 through the Ministry of Research and Technology. The system is still running to this day, spend less operational costs compared to the use of diesel in the previous system. In this paper, the analysis will be conducted to compare the dieselpowered water pumping systems with water pumping system powered solar panel from an economic standpoint, which aims to determine which system is better, reliable, and inexpensive.

\section{Material and method}

- Determined measurement parameters

The economical comparison between photovoltaic system and diesel system needs some parameters such as initial cost, operation cost, maintenance cost, and power generated by those systems. 
- Lifecycle cost calculation analysis

Using parameters that has been determined before, it can be estimated the total amount of cost that should be spent during operation named the lifecycle cost [1]. The lowest lifecycle cost between these systems will be acknowledged as the best system.

- Analysis using HOMER simulation

The other method to compare both systems is calculation using HOMER software. This method will show the ratio of initial capital cost to the energy $(\mathrm{kWh})$ generated by both systems.

\section{Results and discussions}

\subsection{Lifecycle cost calculation}

\subsubsection{Assumption}

In the calculations to be performed, water pumping systems with solar cells (PV) is feasible if the lifecycle cost is lower than the other power supply system, which is diesel. Although wind turbines and electricity on the grid could also be an alternative power suppliers but these are beyond the limits of research conducted.

Lifecycle cost consists of capital costs, maintenance costs, operational costs, fuel costs and equipment salvage value [2]. This calculation method approximated by using a discounted cash flow ratio (DCF) [3]. By using DCF, all future costs such as maintenance after two years will be converted to the equivalent present value with a discount rate, it is assumed that the interest rate is constant. The discount rate assumes that the difference between inflation and the interest rate on bank charges is constant. Future costs will be converted to present value using the following formula:

$$
P V=\frac{F V}{(1+i)^{x}}
$$

$\mathrm{PV}$ is the Present Value (\$), $\mathrm{FV}$ is the Future Value $(\$), i$ shows the discount rate $(\% / \mathrm{yr})$, and $x$ is the number of years which is expected to take place expenditures. Keep in mind that the pump is assumed to be the same so there is no cost replacement of pumps, the difference is only in the power supply system. Therefore, the financing is not included in this calculation is the cost of construction of reservoirs and water distribution systems. Both types of power supply, diesel and solar cells, are also assumed to both work independently of each other. All of the value technical solar array parameters and load are based on source [2].

\subsubsection{Capital cost}

Capital cost of PV arrangement, the cable network, supporting structure, installation, inverters and associated electronic components can be calculated using the following formula [2]:

$$
C_{P V}=W_{P} U_{P V}
$$

$\mathrm{C}_{\mathrm{PV}} \quad$ : Capital costs of the composition of solar panels $(\$)$

$\mathrm{W}_{\mathrm{P}} \quad$ : Power of each arrangement $(\mathrm{W})$

$\mathrm{U}_{\mathrm{PV}} \quad$ : Costs per watt unit $(\$)$

Power rating between the generator and the diesel pump is calculated using the following formula [2]:

$$
P_{\text {genyate }}=\frac{P_{D}}{F}
$$

$\mathrm{P}_{\text {gen,rate }} \quad$ : Power rating of the diesel $(\mathrm{kW})$

$\mathrm{P}_{\mathrm{p}} \quad$ : Pump power (W) 


\section{F $\quad$ : Load Factor}

Capital Cost of diesel was calculated using the following approach:

$$
C_{\text {gen }}=\$ 234.23 P_{\text {gen } r a t e d}+\$ 3400
$$

This formula refers to the source [2]. This value includes the costs assumed for electronic components, and installation costs $10 \%$ of the retail price. Thus, the total of capital costs for diesel, $\mathrm{C}_{\text {diesel }}$, will be the same as the formula above with $\mathrm{C}_{\mathrm{gen}}$.

\subsubsection{Operating and maintenance cost}

Annual operation and maintenance costs as well as the value of the net present value of each component is calculated using the following formula [2]:

$$
P V=A \frac{(1-i)^{n}-1}{i(1+i)^{n}}
$$

$\mathrm{A}$ is the annual cost $(\$), \mathrm{i}$ is the annual discount rate $(\% / \mathrm{yr})$ and $\mathrm{n}$ is the lifetime of the system (yr). Operation and maintenance costs for PV systems called $\mathrm{C}_{\mathrm{o} \& \mathrm{~m}, \mathrm{PV}}$, which is a function of the cost of cleaning the panel, and inverter replacement. The correlation is illustrated in the following equation [2]:

$$
C_{\text {olmpV }}=P_{\text {cleaning }}+P_{\text {inw }}
$$

$\mathrm{P}_{\text {cleaning }}$ is the NPV (net present value) of the cost of cleaning the panel, $\mathrm{P}_{\text {inv }}$ is the NPV of the cost of replacing the inverter. It is assumed that the entire panel be manually cleaned once a month. Wages of workers in accordance with the minimum wage in the district of Gunung Kidul.

$\mathrm{P}_{\text {inv }}$ calculated using the following formula [2]:

$$
P_{\text {inv }}=U_{i m} W_{p}(1+i)^{-y}
$$

$\mathrm{P}_{\mathrm{inv}}$ is the NPV of the cost of electronics, $\mathrm{U}_{\mathrm{inv}}$ is a unit cost of electronics in the $\$ / \mathrm{Wt}$, $\mathrm{i}$ is the annual discount rate, and $\mathrm{y}$ is the difference between the present time and date on which the electronic components to be replaced, and $\mathrm{Wp}$ is the power of the solar cell.

Diesel system has several components that must be replaced periodically as water, fuel, lubricants and water

\begin{tabular}{|c|c|c|c|c|c|}
\hline Diesel system component & $\begin{array}{l}\text { Price per unit } \\
\text { (USD) }\end{array}$ & $\begin{array}{l}\text { Replacement } \\
\text { frequency }\end{array}$ & Duration (h) & Labor cost (USD) & $\begin{array}{c}\text { Total cost per event } \\
\text { (USD) }\end{array}$ \\
\hline Air filter $\left(\mathrm{C}_{\mathrm{M}, \mathrm{air}}\right)$ & $80 /$ filter & 600 & 2 & 61.12 & 114.12 \\
\hline $\begin{array}{l}\text { Oil/fuel/water separator } \\
\text { filter }\left(C_{M} \text {,oil filt }\right)\end{array}$ & 50/filter & 300 & 2 & 61.12 & 111.12 \\
\hline $\begin{array}{l}\text { Lubrication oil change ( } \\
\left.\mathrm{C}_{\mathrm{M} \text {,oil }}\right)\end{array}$ & $8.32 / \mathrm{L}$ & 250 & 0.67 & 20.37 & Coil $(8.32)+20.37$ \\
\hline $\begin{array}{l}\text { Engine coolant change ( } \\
\left.\mathrm{C}_{\mathrm{M}, \text { cool }}\right)\end{array}$ & $1.65 / \mathrm{L}$ & 12000 & 0.67 & 20.37 & $\operatorname{Cool}(1.65)+20.3$ \\
\hline
\end{tabular}
separator filters. Lubricating and cooling fluid should be replaced periodically with a certain frequency. Based on data from the source [2] obtained the following data:

Table 1. Calculation of maintenance cost for diesel system.

Where $\mathrm{C}_{\text {cool }}$ is the capacity of the engine coolant tank and $\mathrm{C}_{\text {oil }}$ is a lubricating oil tank capacity.

The equation for the amount of time during the hours of operation of the diesel in the year are as follows:

$$
H_{d}=G_{d} H_{p}
$$


$\mathrm{H}_{\mathrm{d}}$ is the total amount of time during the operational hours of diesel in a year (hours), $\mathrm{G}_{\mathrm{d}}$ is the time in hours of diesel operation for a year. $\mathrm{H}_{\mathrm{p}}$ is the number of days in a year [2].

The frequency of maintenance in a year, $F_{M}$ described in the following formula

$$
F_{M}=\frac{H_{d}}{F_{E}}
$$

$\mathrm{F}_{\mathrm{E}}$ is the replacement frequency which can be seen in the table. The cost of maintenance for each specific purpose $\mathrm{C}_{\mathrm{M}}$, is shown by the following equation:

$$
C_{M}=C_{E} F_{M}
$$

$\mathrm{C}_{\mathrm{E}}$ is the cost incurred for each specific purpose of maintenance, such as in Table 1 .

From data presented in Table 1, the total cost for maintenance is :

$$
A_{\text {OSM } M_{d}}=C_{M_{c} \text { cool }}+C_{M_{\text {Mair }}}+C_{M_{i} \text { oil filt }}+C_{M_{\text {oil }}}
$$

This equation is then converted to a formula for the calculation of PV for 20 years.

\subsubsection{Fuel cost}

In calculating the cost of this course, the Photovoltaic does not require any fuel. The calculation of the cost of fuel consumption based on the following formula

$$
C_{\text {diesel fuel }}=U_{N P V \text { diesel }} \times V \times D a y
$$

$\mathrm{U}_{\mathrm{NPV} \text {,diesel }}$ price of subsidized diesel fuel (\$), and $\mathrm{V}$ is the number of litres of fuel needed in a day (L), and the day is the number of days in a year in which diesel operated.

\subsubsection{Total lifetime cost}

The total lifetime cost of each system is the sum of each of the adjustments described. Data of costs in Table 2 is converted to Indonesian Rupiah (IDR) to get better understanding.

\begin{tabular}{ll} 
Table 2. Cost for PV system. & \\
\hline Cost of panels & Rp 192000000 \\
Cost of maintenance labor & Rp145 406 085 \\
Cost of electronics replacement & Rp352 062 349.85 \\
Annual maintenance cost & Rp145 406 085 \\
Lifetime maintenance cost & Rp497 468 435 \\
Total system cost & Rp689 468 434.76 \\
\hline & \\
Table 3. Cost for diesel system. & \\
\hline Cost of diesel engine/generator & \\
Installation & Rp38 136151.43 \\
Maintenance and operating cost & Rp4 785 000 \\
Lifetime fuel costs & Rp92 071 124.14 \\
Total lifecycle cost & Rp738 470 743.41 \\
\hline
\end{tabular}

From the above data we can take the conclusion that the construction of the diesel system is still more expensive than the construction of the PV system. Based on these data shows that the ratio of the total cost of PV systems with a diesel system is equal to $3: 4$. Fig. 1 shows the total cost of both technologies for 20 years operating time. 


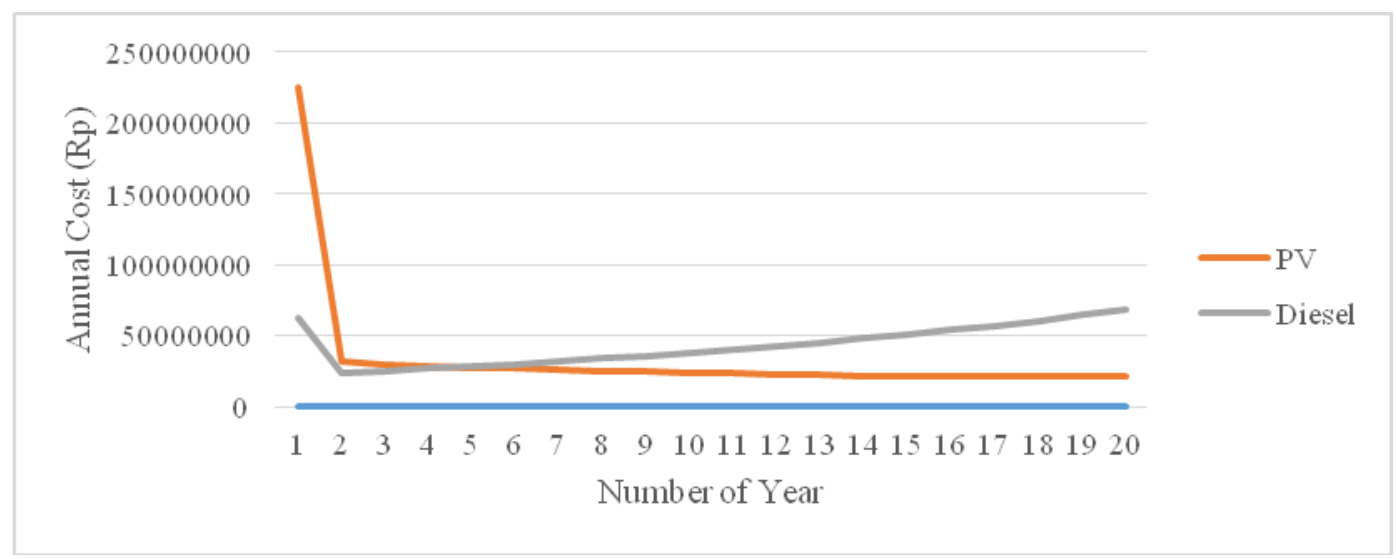

Fig.1 Comparison dynamics cost for 20 years chart of PV system and diesel system.

\subsection{Analysis using HOMER simulation}

HOMER software is used to optimize and analyze the system in terms of economic sustainability. For the simulation using HOMER, required input data such as hourly load profile, solar radiation per month throughout the year, the value of the initial capital for each component (PV, battery, inverter, generator), the price of diesel fuel, and the cost of managing each year. Solar radiation data obtained from NASA. The initial cost of the prices of the components are mounted on the SWPS system in Tepus village. Load profile obtained from a number of electricity needs in the location system.

HOMER simulates the operation of the system by calculating the balance of energy every hour from 8760 hours total throughout the year. The simulation results in the form of total Net Present Cost (NPC) will be displayed. NPC is the life cycle cost of the system. Calculation required to estimate all costs during the lifetime of the project, including initial cost, replacement parts, repairs, and fuel costs.

Simulations were performed to analyze the energy source which is more optimally used to drive pumps for water removal. Two types of plants were simulated PV is now being used as well as the previously used diesel generators.

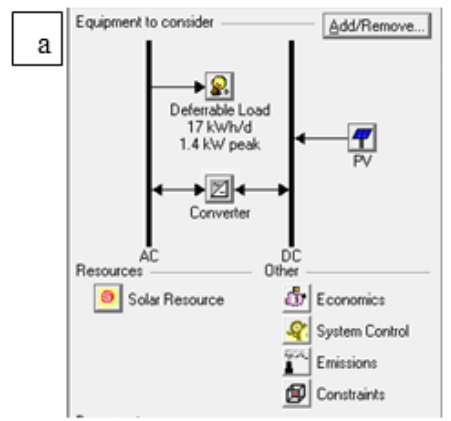

\begin{tabular}{|l|l|l|c|c|c|c|c|c|c|c|}
\hline $\mathrm{b}$ & $\begin{array}{c}\mathrm{PV} \\
\mathrm{kW})\end{array}$ & $\begin{array}{c}\text { Conv. } \\
\mathrm{kW})\end{array}$ & $\begin{array}{c}\text { Initial } \\
\text { Capital }\end{array}$ & $\begin{array}{c}\text { Operating } \\
\text { Cost }(\$ / \mathrm{yr})\end{array}$ & $\begin{array}{c}\text { Total } \\
\mathrm{NPC}\end{array}$ & $\begin{array}{c}\text { COE } \\
(\mathrm{S} / \mathrm{kWh})\end{array}$ & $\begin{array}{c}\text { Ren. } \\
\text { Frac. }\end{array}$ & $\begin{array}{c}\text { Capacity } \\
\text { Shortage }\end{array}$ \\
\hline
\end{tabular}

Fig.2 (a) Schematic of PV power system; (b) simulation result of PV power system.

Fig.2.(a) shows the scheme of the PV power plant sourced. In this system, the electricity generated is used as a pump drive directly without using the battery due to the efficiency of the system only works during the day. 
Fig.2.(b) simulation results show the total value of the PV power system for NPC $\$ 17,809$ and cost of energy (COE) $\$ 0.312 / \mathrm{kWh}$.

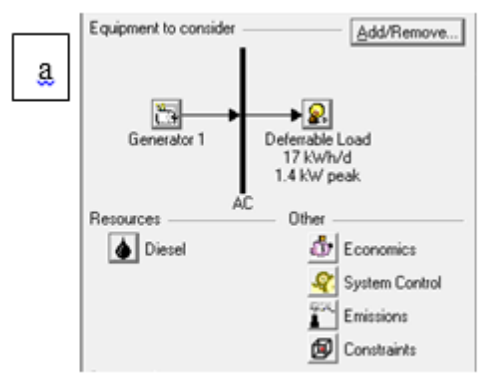

\begin{tabular}{|c|c|c|c|c|c|c|c|c|}
\hline $\mathrm{b}$ & \begin{tabular}{|l|l|}
13 & Label \\
$(\mathrm{kW})$
\end{tabular} & $\begin{array}{c}\text { Intial } \\
\text { Caphtal }\end{array}$ & $\begin{array}{l}\text { Operating } \\
\text { Cost }(\$ / y i)\end{array}$ & $\begin{array}{l}\text { Total } \\
\text { NPC }\end{array}$ & \begin{tabular}{|c|}
$\mathrm{COE}$ \\
$(\mathrm{S} / \mathrm{kWh})$
\end{tabular} & $\begin{array}{l}\text { Ren. } \\
\text { Frac. }\end{array}$ & $\begin{array}{l}\text { Diesel } \\
\text { (L) }\end{array}$ & $\begin{array}{l}\text { Label } \\
\text { (hrs) }\end{array}$ \\
\hline & 4.8 & $\$ 89$ & 2.315 & $\$ 30.488$ & 0.390 & 0.00 & 3.250 & 4.369 \\
\hline
\end{tabular}

Fig.3 (a) Schematic of diesel generator power system; (b) simulation result of diesel generator power system.

Fig.3.(a) schematic shows the generation of electricity by diesel generators. The simulation results shown in Fig.3.(b). From the simulation results obtained total value of $\$ 30.488 \mathrm{NPC}$ and the cost of energy (COE) of $\$ 0.390 / \mathrm{kWh}$.

Although the initial capital installation of diesel is much cheaper than PV, both simulation results indicate that the source of power generation in terms of the economy, the overall PV system power is cheaper than diesel generator power system. It can be shown from the total value of the NPC and the cost of energy for every kWh.

\subsection{Analysis from community perspective}

This analysis is done to measure the satisfaction felt by the public to the existence of the two systems. The analysis was carried out on the terms of the conditions that occur in Sureng village, as the village had ever used both systems.

Before the construction of Solar Water Pumping System (SWPS), people use diesel pumps to lift the water into their village. During the use of diesel systems, to obtain 40 litres of water residents must pay $\$ 1500$, equivalent to $\$ 37.5 / \mathrm{L}$. Meanwhile, after the construction of SWPS, residents only need to pay $\$ 500$ to get $40 \mathrm{~L}$ of water, equivalent to $\$ 12.5 / \mathrm{L}$.

However, the existence of the two systems is still not able to help the community to meet the needs of water in his house. This is because people have to take their own water from reservoirs, so it is quite difficult to get a large volume of water. Some people who do not want the hassle of taking water from the reservoir would prefer to buy water from the water truck services for $150000 \mathrm{~L}$ to $5000 \mathrm{~L}$ of water, equivalent to $\$ 30 / \mathrm{L}$.

Table 4. Selling price of Solar Water Pumping System (SWPS) and diesel pump.

\begin{tabular}{lccc}
\hline & SWPS & Diesel pump & Water truck service \\
\hline Price & $\$ 12.5 / \mathrm{L}$ & $\$ 37.5 / \mathrm{L}$ & $\$ 30 / \mathrm{L}$ \\
Minimum purchase amount $(\mathrm{L})$ & $40 \mathrm{~L}$ & $40 \mathrm{~L}$ & $5000 \mathrm{~L}$ \\
\hline
\end{tabular}

From the description above, we can see that the SWPS is the water system with the lowest selling price by $\$ 12.5 / \mathrm{L}$. Meanwhile, the diesel pump is the most expensive system with water selling price $\$ 37.5 / \mathrm{L}$. However, in reality, people still tend to buy water from the water truck service that sells the water at $\$ 30 / \mathrm{L}$, because people do not need to take water from the reservoir. 
Furthermore, all parties involved in the development of this SWPS will strive to enhance the SWPS system into direct water connections to houses, so that people can use the water immediately at home without having to take out of the shelter.

\section{Conclusions}

The economical comparison between solar PV and diesel pump were analyzed using lifecycle cost calculation and HOMER simulation. The analysis provided that using photovoltaic for water pumping system only spend $2 / 3$ times of diesel generator cost. On the other hand, HOMER analysis shows that the COE value for photovoltaic usage is $0.312 \$ / \mathrm{kWh}$, and COE value for diesel generator is $0.390 \$ / \mathrm{kWh}$.

Photovoltaic technology is the appropriate technology for water pumping energy source that can be implemented in rural area as Tepus district, Gunung Kidul, DIY. This analysis use subsidized fuel price in Indonesia, it points out that the chance of renewable energy development could be cheaper than conventional energy.

\section{Acknowledgements}

Author would like to thank The Institute of Research and Community Service (LPPM) UGM for providing the Research Project Funding through TTG Grant and Department of Engineering Physics Universitas Gadjah Mada.

\section{References}

[1]Setiawan A A, Purwanto D H, Pamuji D S, Huda N. Development of a Solar Water Pumping System in Karsts Rural Area Tepus, Gunungkidul through Student Community Services. Energy Procedia, 2014, Vol. 47 p. 7-14.

[2]Leah C Kelley,Eric Gilbertson,Anwar Sheikh,Steven D Eppinger,Steven Dubowsky. On the Feasibility of Solar-powered Irigation. Renewable and Sustainable Energy Reviews 2010; Vol 14 p. 2669-2682.

[3]White J, Case K, Pratt D. Principles of Engineering Economic Analysis. Hoboken: NJ. Wiley Higher Education;2010.

[4]Aligah, Abu, Design of Photovoltaic Water Pumping System and Compare it with Diesel Powered Pump. JJMIE 2010; Vol. 5 No.3 pp 273280.

[5]Arrohman, Roni E. Design solar water Pumping System in Tepus District, Gunungkidul Regency. [Thesis]. Department of Engineering Physics. Universitas Gadjah Mada; 2012. 